over two years. The new judiciary will operate at four levels: village courts, for disputes involving small sums of money; community courts, in both rural and urban areas, for more complicated cases and for appeals from village courts; magistrates courts, for criminal and major civil cases and appeals from community court decisions; and the Supreme Court, for final appeals. Village and community court proceedings will be in tribal languages, and decisions will be based largely on customary law. Cases before the two higher courts will continue to be conducted in English.

Foundation funds will be used to train community court judges, some ten from each of Zimbabwe's eight provinces. A foreign legal expert has been engaged to help draft the training curriculum and to monitor the development of the new primary courts. The grant will also cover research aimed at fusing customary and common law into a unified legal system.

The Foundation also made a one-year grant of U.S. $\$ 80,000$ to enable the Ministry of Public Affairs to bring home highly-trained expatriate black Zimbabweans needed for senior civil service posts.

Since independence in 1980 several new government ministries have been created to address Zimbabwe's major problems of rehabilitation and reconstruction and to begin social and economic development programs. Well-trained professionals are urgently needed, particularly since many white senior civil servants have left the country. The grant will cover the costs of repatriating some fifteen professional administrators at the level of assistant secretary or higher, and for such experts as economists, scientists, and engineers.

These two Foundation actions are the first in what is expected to be a broader program of support for Zimbabwean development.

\title{
LAW AND ECONOMICS BIBLIOGRAPHY
}

A new series entitled Bibliography in Law and Economics, bringing together references in major areas of Law and Economics research, was initiated recently by Cento Veljanovski, Centre for Socio-Legal Studies, Wolfson College, Oxford, England. "Contract Analysis" and "Legal Liability and Negligence," the first two bibliographies in the series, are already completed and available by writing the Centre. Professor Veljanovski is soliciting unpublished manuscripts, working papers, and research reports which may be included in future and revised versions. Already in progress are bibliographies of accident law, property rights, crime and criminal law, legal services and judicial procedure, family law, and regulation. The series is certain to provide a valuable service for Law and Economics researchers who may also look forward to seeing it consolidated into one reference volume in the future. 


\section{EUROPEAN COMMUNITIES LEGISLATION :}

\section{A NEW FINDING TOOL}

The office for Official Publications of the European Communities has finally produced a convenient finding tool for current Community legal instruments. Known as the Register of Current Community Legal Instruments, this publication is expected to appear in frequent superseding editions.

The first edition of the Register gives references for all binding Community legislation in force on July 1, 1979. It covers:

-legislation derived from the Treaties establishing the three European Communities,

-supplementary legislation,

-agreements between the Communities and non-member countries.

References are classified by subject. For ease of research the analytical section has two indexes-one of them lists key words in alphabetical order and the other is a list of numbers. References to law that cover several different subjects appear under each of the relevant subject headings. Wherever a law is amended there is a full reference to the amending law. Most of the citations are to the Official Journal of the European Communities.

The Register consists of two volumes. The first contains the analytical section, the alphabetical index and guidance for the reader. The second is the chronological index by number of all the laws given in the analytical section.

Published in all of the Community languages, the Register is available from the Office for Official Publications, B. P. 1003, Luxembourg. 